\title{
Effect of Microwave Processing and Storage on Quality of Cajuput (Melaleuca cajuputi) Honey from Bac Lieu-Vietnam
}

\author{
Nguyen Xuan Nam ${ }^{1 *}$, Nguyen Chi Phuc ${ }^{1}$, Phan Phuoc Hien ${ }^{2}$ and Huynh Ngoc Oanh ${ }^{1}$ \\ ${ }^{1}$ Ho Chi Minh City University of Technology, Vietnam \\ ${ }^{2}$ Southern Cantho University, Vietnam
}

Submission: January 29, 2018; Published: March 22, 2018

*Corresponding author: Nguyen Xuan Nam, Ho Chi Minh City University of Technology, Vietnam, Email: nx.nam@hutech.edu.vn

\begin{abstract}
The aim of the present work was to find out if microwave processing and storage conditions can affect some of the main honey quality paramenters (reducing sugar (RS), hydroxymethylfurfural (HMF), diastase number (DN), water and colour) of cajuput honey was obtained from Bac Lieu-Vietnam. RS content were analyzed by DNS method, HMF under AOAC 980.23, diastase activity based on AOAC 958.09, water content according to AOAC $969.38 \mathrm{~B}$ and colour parameters $\left(\mathrm{L}^{*}, \mathrm{a}^{*}, \mathrm{~b}^{*}\right)$ were established in the CIE system. The results of the analysis showed that the physico-chemical characteristics of fresh honey was as follows: water content $23.18 \%$, RS $717.42 \mathrm{mg} / \mathrm{g}, \mathrm{HMF} 4.24 \mathrm{mg} / \mathrm{kg}$, DN $4.85 \mathrm{mg} / \mathrm{kg}$, colour parameters $\mathrm{L}^{*} \mathrm{a}^{*} \mathrm{~b}^{*}$ 39.51-10.51-31.81. Honey was processed at continues power 30P(480 W), 50P(800 W), 70P(1120 W) for 20, 30, and 40 seconds then the honey sample was left to room temperature $\left(20-23^{\circ} \mathrm{C}\right)$, stored at room $\left(<25^{\circ} \mathrm{C}\right)$ and $\operatorname{cool}\left(<10^{\circ} \mathrm{C}\right)$ temperature for eight weeks. The changes in the RS, HMF, DN, water and colour were observed. Microwave processing applied to cajuput honey did not effect on colour, while RS, HMF, DN and water content affected significantly. The storage time and temperature affected significantly on RS, DN and colour.
\end{abstract}

Keywords: Honey; Microwave processing; Storage; Reducing sugar; Hydroxymethylfurfural; diastase number; Water; Colour

\section{Introduction}

Honey is natural sweet substance produced by honey bees from the nectar of plants or from secretions of living parts of plants or excretions of plant-sucking insects on the living parts of plants which the bees collect and transform by combining it with specific substances of their own, dehydrate, store and leave in honeycombs to mature and ripen [1].

It is well known that honey as a natural product may be processed by means of heat processing for two main reasons: first of all, to destroy the micro-organisms that may contaminate it and to modify its tendency to crystallisation or delay the appearance of monosaccharide crystals [2]. During crystallisation that leads to phase separation, both liquid and non-liquid phases may coexist. Simultaneously, water activity of the remaining liquid phase begins to increase. This is the result of water release during crystallisation and subsequent decrease of carbohydrates concentration in the liquid phase. This phenomenon makes the honey suitable for the growth of microorganisms like yeasts and fungi and leads to sensory properties modifications and quality damage [3].

Microwave processing may be the solution for honey liquefaction without the loss of bioactivity. Microwaves as an example of volumetric heating will influence the state of aggregation and due to the microwave/matter interaction may be applied for a short time. It results in reduction of quality losses in honey [4]. On the other hand it is well known that microwave processing can cause some damage to bioactive food components (especially enzymes) [5,6].

Therefore, in this work, we aimed to evaluate the effect of microwave processing and storage on the honey quality.

\section{Material and Methods}

Cajuput honey were obtained from Bac Lieu-Vietnam. Microwave processing of the honey samples $(50 \mathrm{~g})$ was performed without stirring in a microwave reactor operating (power level input $1600 \mathrm{~W}=32 \mathrm{~W} / \mathrm{g}=100 \mathrm{P}$ ) with continues power $30 \mathrm{P}(9.6 \mathrm{~W} / \mathrm{g}), 50 \mathrm{P}(16 \mathrm{~W} / \mathrm{g}), 70 \mathrm{P}(22.4 \mathrm{~W} / \mathrm{g})$, for 20,30 , and 40 seconds.

After all treatments and cooling of the samples to room temperature, RS, HMF, DN, water content and colour were determined as a function of time. Beside that, honey was stored at room $\left(<25^{\circ} \mathrm{C}\right)$ and $\operatorname{cool}\left(<10^{\circ} \mathrm{C}\right)$ temperature for eight weeks, analyzed the main honey quality. RS can be investigated by the 3,5-dinitrosalicylic acid (DNS) method employing glucose as the 
standard at 540nm [7]. HMF content is based on AOAC 980.23. DN is based on AOAC 958.09. Water content is based on AOAC 969.38B. Colour parameters $\left(\mathrm{L}^{*}, \mathrm{a}^{*}, \mathrm{~b}^{*}\right)$ were established in the CIE system using a Minolta Chroma-meter (CR-200 Series, Osaka, Japan).The data obtained in the study were analyzed statistically using analysis of variance (ANOVA) with statistically significant $(\mathrm{P}<0.05)$.

\section{Results and Discussion}

The composition of honey depends on produced season, origin of nectar and climatic conditions [8]. The most important factor affecting honey composition is plant origin [9]. The Table 1: Physicochemical composition of cajuput honey. chemical components of the fresh honey sample are shown in Table 1. Water content of cajuput honey (23.18\%) higher than Codex standard 12-1981 $(<20 \%)$. Water content is highly important for the shelf-life of the honey during storage because a high water content causes honey to ferment and spoil [10]. RS content $(717.42 \mathrm{mg} / \mathrm{g},>600 \mathrm{mg} / \mathrm{g})$, HMF content $(4.24 \mathrm{mg} /$ $\mathrm{kg},<40 \mathrm{mg} / \mathrm{kg})$ and DN content $(4.85 \mathrm{mg} / \mathrm{kg}, \geq 3 \mathrm{mg} / \mathrm{kg})$ were satisfied Codex standard. DN and HMF are considered as the main parameters for evaluating: the freshness, the heat and storage history of honey [11]. The color of honey is one of the most factors used to assess the quality of honey. The results showed that color of cajuput honey so dark $\left(L^{*}=39.51\right)$.

\begin{tabular}{|c|c|}
\hline Physicochemical composition & Contents \\
\hline Water (\%) & $23.18 \pm 0.72$ \\
\hline RS (mg/g) & $717.42 \pm 8.34$ \\
\hline $\mathrm{HMF}(\mathrm{mg} / \mathrm{kg})$ & $4.24 \pm 0.31$ \\
\hline $\mathrm{DN}(\mathrm{mg} / \mathrm{kg})$ & $4.85 \pm 0.24$ \\
\hline $\mathrm{L}^{*}$ & $39.51 \pm 0.14$ \\
\hline $\mathrm{a}^{*}$ & $10.51 \pm 0.06$ \\
\hline $\mathrm{b}^{*}$ & $31.81 \pm 0.23$ \\
\hline
\end{tabular}

Table 2: Effect of microwave processing on honey quality.

\begin{tabular}{|c|c|c|c|c|c|}
\hline $\begin{array}{c}\text { Processing } \\
\text { conditions (Power- } \\
\text { Time) }\end{array}$ & RS (mg/g) & HMF $\mathbf{( m g} / \mathbf{k g})$ & DN (mg/kg) & Water content (\%) & $\Delta \mathbf{E}$ \\
\hline Before treatment & $717.42 \mathrm{a} * \pm 8.34$ & $4.24 \mathrm{a} \pm 0.31$ & $4.85 \mathrm{bc} \pm 0.24$ & $23.18 \mathrm{a} \pm 0.72$ & 0.00 \\
\hline $30 \mathrm{P}-20 \mathrm{sec}$ & $715.04 \mathrm{a} \pm 19.35$ & $5.04 \mathrm{~b} \pm 0.43$ & $4.63 \mathrm{c} \pm 0.38$ & $22.85 \mathrm{a} \pm 0.88$ & 0.07 \\
\hline $30 \mathrm{P}-30 \mathrm{sec}$ & $724.54 \mathrm{ab} \pm 4.94$ & $5.49 \mathrm{~b} \pm 0.46$ & $5.54 \mathrm{ab} \pm 0.74$ & $21.36 \mathrm{~b} \pm 0.19$ & 0.13 \\
\hline $30 \mathrm{P}-40 \mathrm{sec}$ & $759.38 \mathrm{~cd} \pm 11.88$ & $6.44 \mathrm{c} \pm 0.40$ & $6.05 \mathrm{a} \pm 0.97$ & $21.22 \mathrm{~b} \pm 0.23$ & 0.26 \\
\hline $50 \mathrm{P}-20 \mathrm{sec}$ & $747.51 \mathrm{bc} \pm 12.34$ & $6.99 \mathrm{~cd} \pm 0.17$ & $3.46 \mathrm{~d} \pm 0.15$ & $19.88 \mathrm{c} \pm 1.32$ & 0.19 \\
\hline $50 \mathrm{P}-30 \mathrm{sec}$ & $779.97 \mathrm{de} \pm 9.89$ & $7.49 \mathrm{~d} \pm 0.25$ & $3.64 \mathrm{~d} \pm 0.24$ & $18.67 \mathrm{~cd} \pm 0.43$ & 0.59 \\
\hline $50 \mathrm{P}-40 \mathrm{sec}$ & $816.78 \mathrm{fg} \pm 12.59$ & $8.13 \mathrm{e} \pm 0.31$ & $5.66 \mathrm{ab} \pm 0.73$ & $18.87 \mathrm{~cd} \pm 1.41$ & 0.39 \\
\hline $70 \mathrm{P}-20 \mathrm{sec}$ & $831.09 \mathrm{~g} \pm 16.67$ & $8.08 \mathrm{e} \pm 0.30$ & $3.46 \mathrm{~d} \pm 0.06$ & $17.64 \mathrm{~d} \pm 0.63$ & 0.62 \\
\hline $70 \mathrm{P}-30 \mathrm{sec}$ & $795.42 \mathrm{ef} \pm 7.96$ & $8.93 \mathrm{f} \pm 0.31$ & $4.63 \mathrm{c} \pm 0.44$ & $18.31 \mathrm{de} \pm 0.39$ & 0.59 \\
\hline $70 \mathrm{P}-40 \mathrm{sec}$ & $777.86 \mathrm{de} \pm 25.13$ & $8.38 \mathrm{ef} \pm 0.40$ & $3.62 \mathrm{~d} \pm 0.46$ & $16.87 \mathrm{e} \pm 0.24$ & 0.64 \\
\hline
\end{tabular}

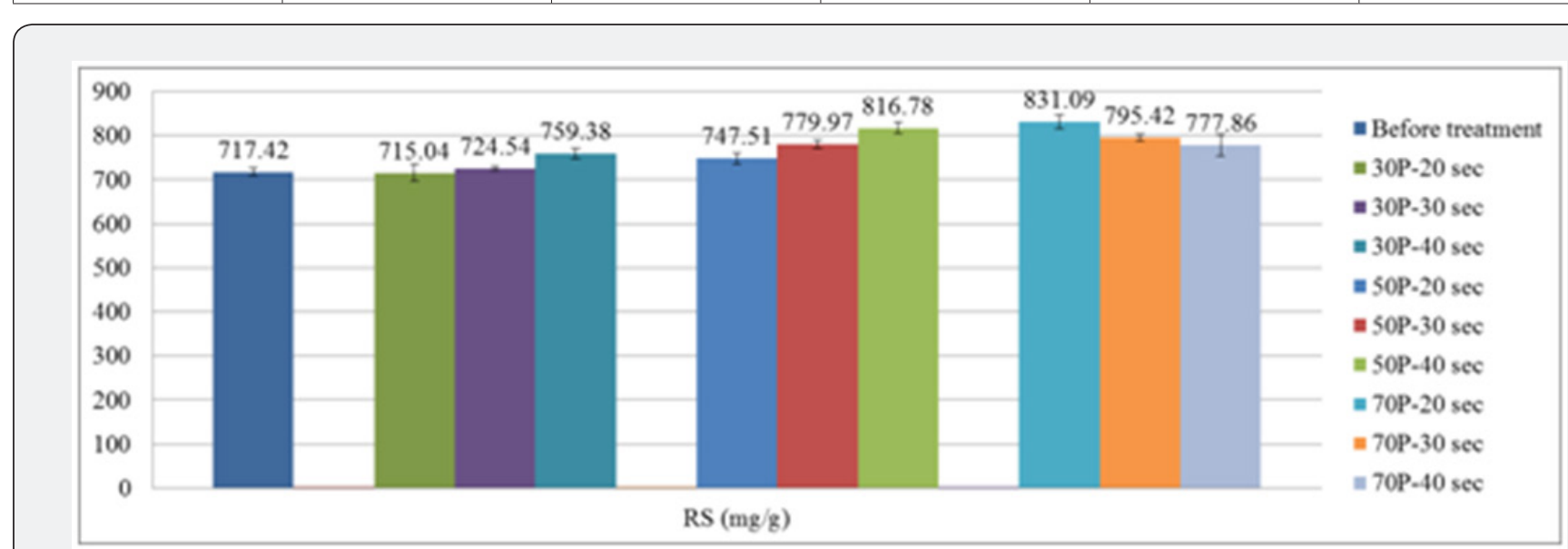

Figure 1: Effect of microwave processing on RS. 
The values of RS content in different power are summarized in Table 2 \& Figure 1 . The changes of RS content in the honey sample according to 9 treatments had fluctuated but not significantly until 50P-30 sec $(779.97 \mathrm{mg} / \mathrm{g})$. However, the RS did not less than $600 \mathrm{mg} / \mathrm{g}$ (Codex Standard 12-1981).

The initial content of HMF was low in the honey and the processing to which honey sample was increased depend on the processing conditions. According to 9 treatments, HMF raised continuously, although according to different ratio are summarized in Table 2 \& Figure 2. At 30P in 20- $40 \mathrm{sec}$, HMF from $5.04-6.44 \mathrm{mg} / \mathrm{kg}$. At $50 \mathrm{P}$ in $20-40 \mathrm{sec}$, HMF from 6.99 $8.13 \mathrm{mg} / \mathrm{kg}$. At 70P, HMF increased $49.52 \%$ (compare with fresh honey). However, the HMF did not more than $40 \mathrm{mg} / \mathrm{kg}$ (Codex Standard 12-1981).

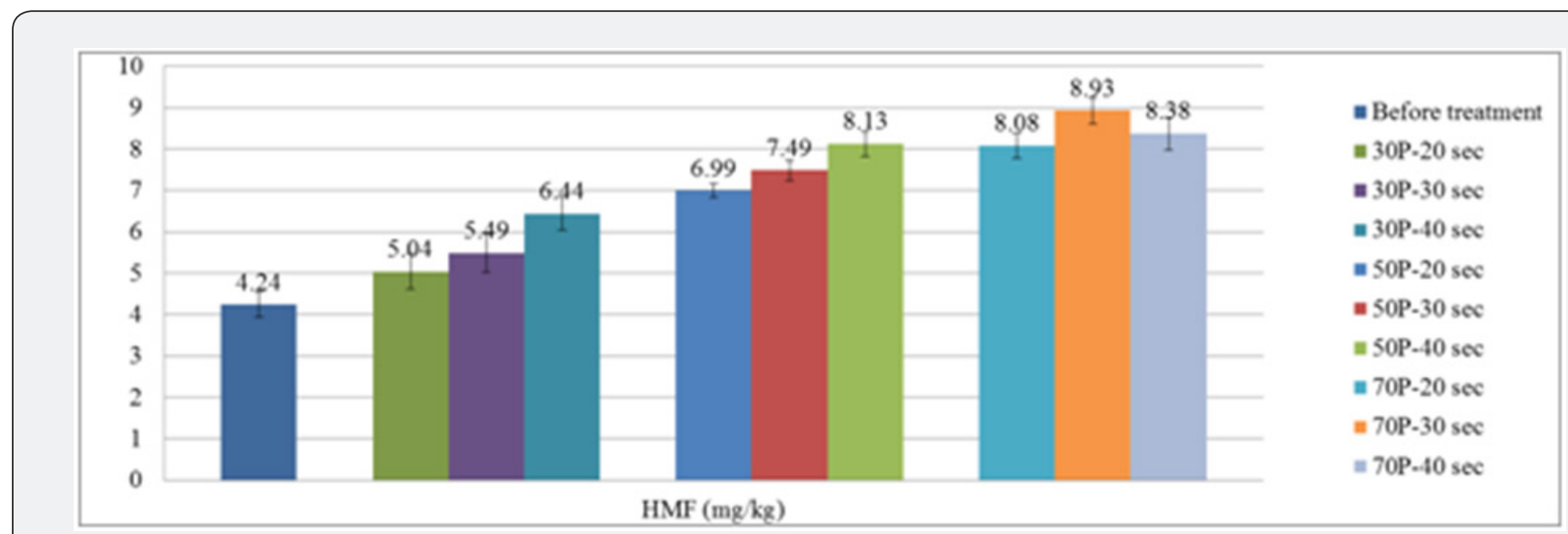

Figure 2: Effect of microwave processing on HMF.

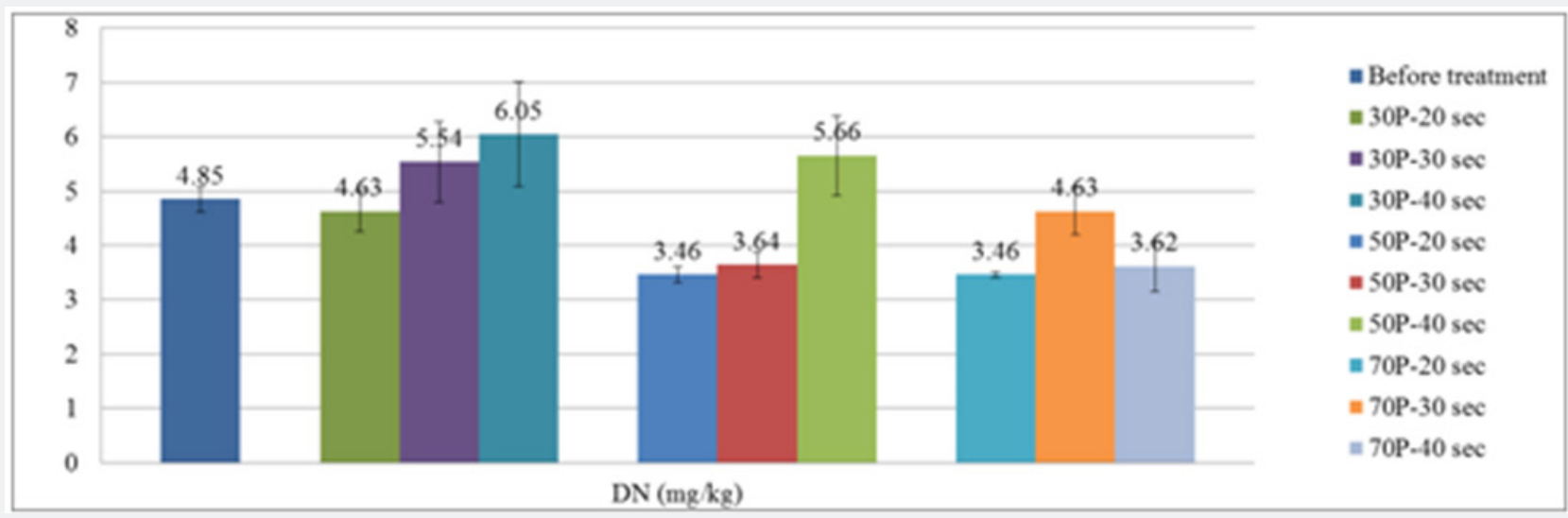

Figure 3: Effect of microwave processing on DN.

The values of DN in different power and time are summarized in Table 2 \& Figure 3. DN had fluctuated according to treatments (from $4.63-6.05 \mathrm{mg} / \mathrm{kg}$ at $30 \mathrm{P}$, from $3.46-5.66 \mathrm{mg} / \mathrm{kg}$ at $50 \mathrm{P}$ and from $3.46-3.62 \mathrm{mg} / \mathrm{kg}$ at $70 \mathrm{P}$ ) but not less than $3 \mathrm{mg} / \mathrm{kg}$ (Codex Standard 12-1981).

The results showed that as the power and time of microwave processing increased, the water content decreased. At 30P, treatment to 30 seconds to made different from the original water. When the power rises to 50P and 70P in 20 seconds, water content was significantly reduced. However, under conditions of $70 \mathrm{P}-40$ seconds, the water content $(16.87 \%)$ was reached to preservative conditions (17-18\%).
The colour of honey is one of the factors determining its price on the world market, and also its acceptability by the consumer. Light honeys are usually mild in flavor and of a higher commercial value than dark coloured honey $[13,14]$. According to 9 treatments, colour of honey had fluctuated but the observator does not feel the difference $(\Delta \mathrm{E}<1)$.

After processing at $50 \mathrm{P}-30 \mathrm{sec}$, honey sample was stored at room $\left(<25{ }^{\circ} \mathrm{C}\right)$ and cool $\left(<10{ }^{\circ} \mathrm{C}\right)$ temperature for eight weeks. The values of RS in different storage conditions are showed in Table 3 \& Figure 4-6. During the storage, there was no significant $(\mathrm{P}<0.05)$ difference among the temperature and time on RS (from 803.72 to $819.56 \mathrm{mg} / \mathrm{g}$ ). 


\section{Current Trends in Biomedical Engineering \& Biosciences}

Table 3: Effect of storage on honey quality after microwave processing at $50 \mathrm{P}-30 \mathrm{sec}$.

\begin{tabular}{|c|c|c|c|c|c|c|}
\hline Time (week) & $\begin{array}{c}\text { Temperature } \\
\left({ }^{\circ} \mathrm{C}\right)\end{array}$ & $\mathrm{RS}$ (mg/g) & HMF (mg/kg) & DN (mg/kg) & $\begin{array}{c}\text { Water content } \\
(\%)\end{array}$ & $\Delta \mathrm{E}$ \\
\hline \multicolumn{2}{|c|}{ Before Treatment } & $717.42 \mathrm{a}^{*} \pm 8.34$ & $4.24 \mathrm{a} \pm 0.31$ & $4.85 b c \pm 0.24$ & $23.18 \mathrm{a} \pm 0.72$ & 0.00 \\
\hline \multicolumn{2}{|c|}{ After Treatment } & $779.97 b \pm 9.89$ & $7.49 b \pm 0.25$ & $3.64 a \pm 0.24$ & $18.67 b c \pm 0.43$ & 0.59 \\
\hline \multirow[t]{2}{*}{2} & $25{ }^{\circ} \mathrm{C}$ & $803.72 b c \pm 16.68$ & $7.43 \mathrm{~b} \pm 0.62$ & $5.52 \mathrm{de} \pm 0.49$ & $19.23 \mathrm{~b} \pm 0.96$ & 2.08 \\
\hline & $10^{\circ} \mathrm{C}$ & $810.06 b c \pm 16.17$ & $7.58 b \pm 0.37$ & $5.22 \mathrm{~cd} \pm 0.48$ & $18.60 \mathrm{bc} \pm 0.41$ & 2.10 \\
\hline \multirow[t]{2}{*}{4} & $25^{\circ} \mathrm{C}$ & $805.30 b c \pm 29.03$ & $7.68 \mathrm{~b} \pm 0.52$ & $5.81 \mathrm{e} \pm 0.43$ & $19.60 \mathrm{~b} \pm 0.67$ & 3.71 \\
\hline & $10{ }^{\circ} \mathrm{C}$ & $808.47 b c \pm 15.81$ & $7.73 b \pm 0.37$ & $5.16 \mathrm{~cd} \pm 0.21$ & $18.92 \mathrm{~b} \pm 0.68$ & 3.00 \\
\hline \multirow[t]{2}{*}{6} & $25^{\circ} \mathrm{C}$ & $817.18 c \pm 26.70$ & $8.03 b c \pm 0.38$ & $5.38 \mathrm{cde} \pm 0.44$ & $19.51 \mathrm{~b} \pm 0.51$ & 5.11 \\
\hline & $10^{\circ} \mathrm{C}$ & $807.68 b c \pm 23.91$ & $7.83 \mathrm{~b} \pm 0.62$ & $4.80 \mathrm{bc} \pm 0.20$ & $17.61 \mathrm{c} \pm 0.37$ & 3.38 \\
\hline \multirow[t]{2}{*}{8} & $25^{\circ} \mathrm{C}$ & $819.56 c \pm 11.23$ & $8.68 c \pm 0.15$ & $4.46 \mathrm{~b} \pm 0.34$ & $19.13 \mathrm{~b} \pm 1.25$ & 7.85 \\
\hline & $10^{\circ} \mathrm{C}$ & $813.22 c \pm 4.94$ & $8.13 b c \pm 0.60$ & $4.37 \mathrm{~b} \pm 0.23$ & $19.28 \mathrm{~b} \pm 1.01$ & 5.50 \\
\hline
\end{tabular}

*Values in columns with the same letter do not differ significantly at $\alpha=0.05$

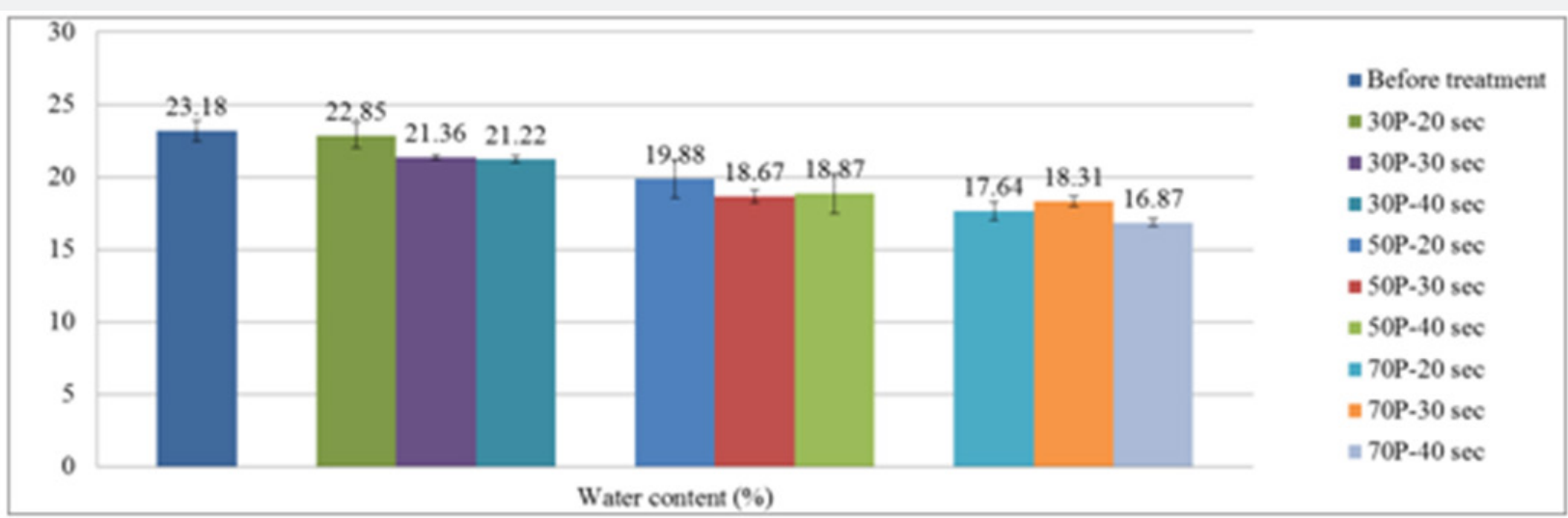

Figure 4: Effect of microwave processing on water content.

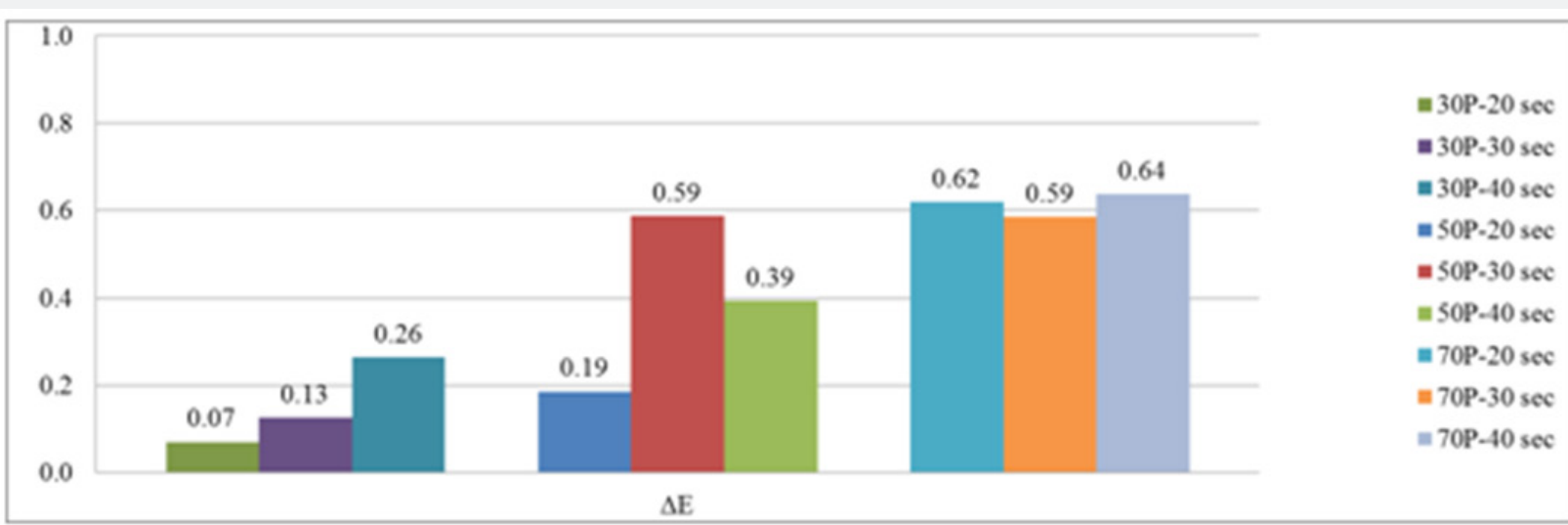

Figure 5: Effect of microwave processing on colour. 


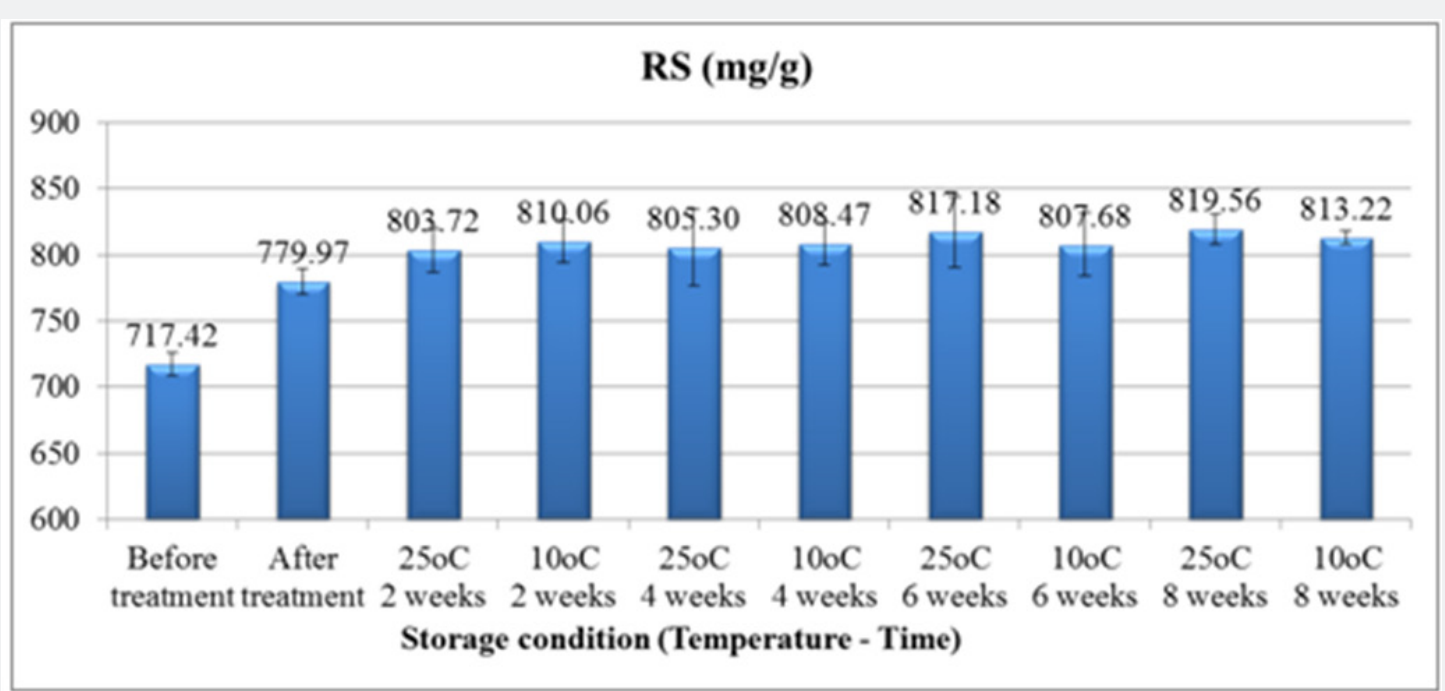

Figure 6: Effect of storage condition after microwave processing on RS.

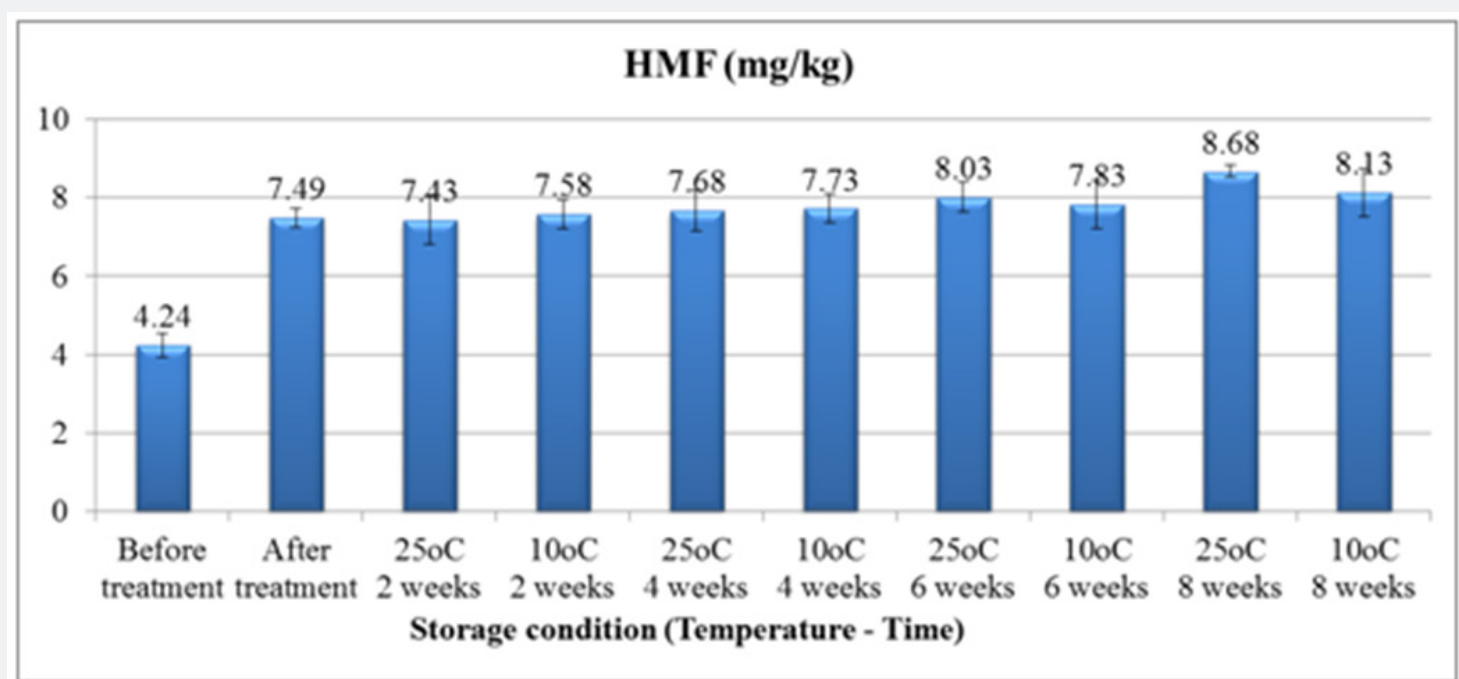

Figure 7: Effect of storage condition after microwave processing on HMF.

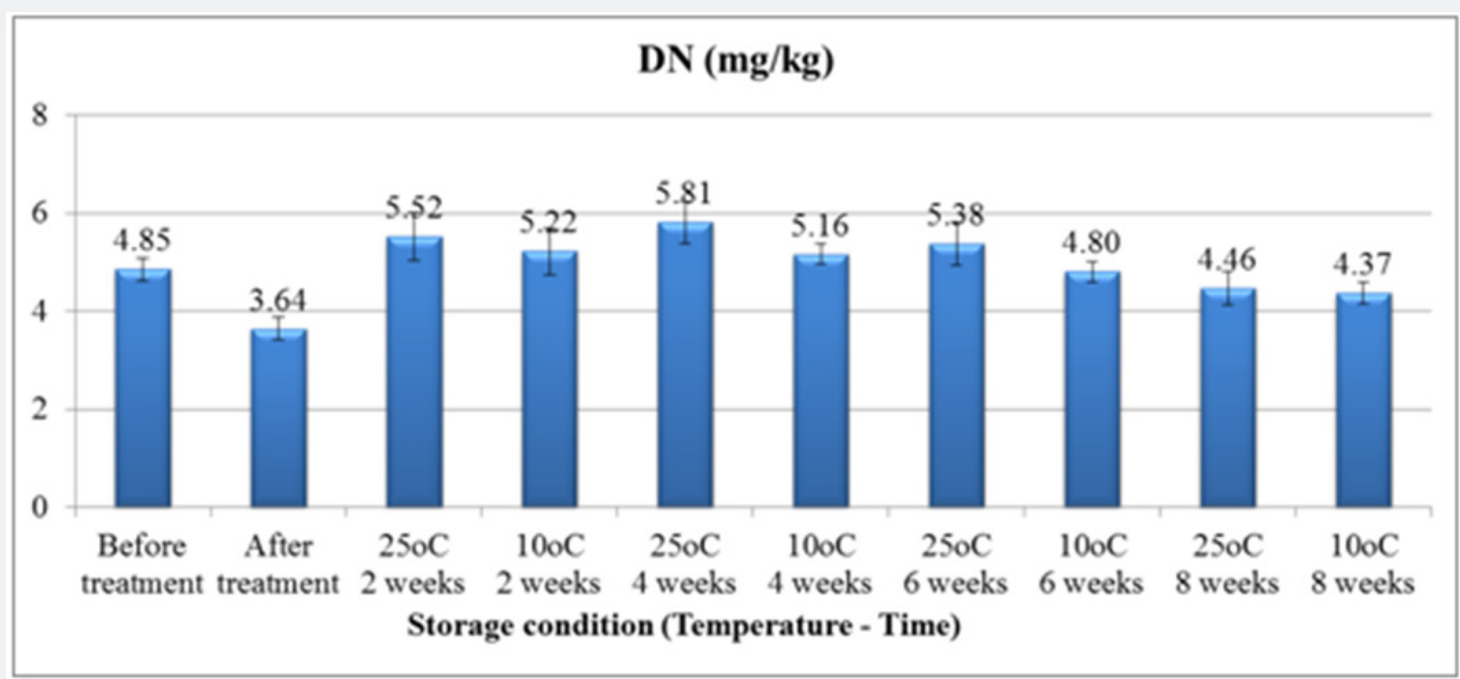

Figure 8: Effect of storage condition after microwave processing on DN. 


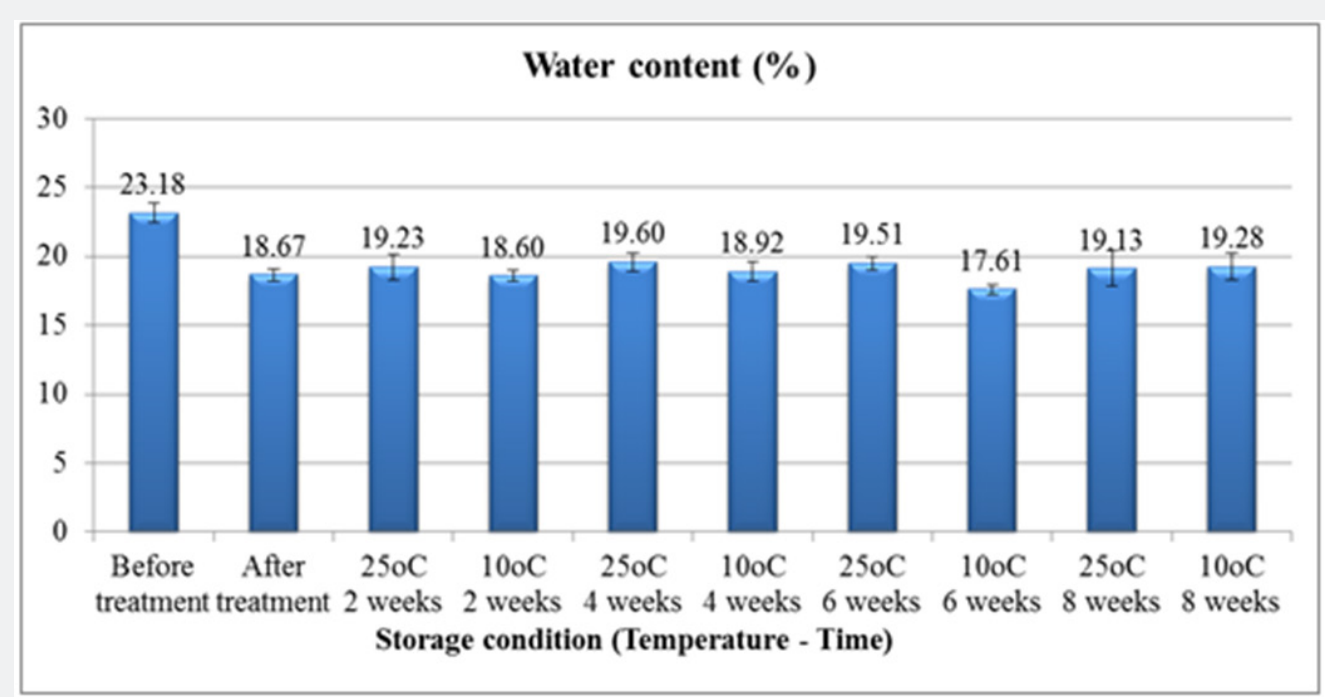

Figure 9: Effect of storage condition after microwave processing on water content.

About HMF content, according to 8 weeks in $25{ }^{\circ} \mathrm{C} \& 10{ }^{\circ} \mathrm{C}$, HMF had increased continously but there was no significant $(\mathrm{P}<0.05)$ difference (except at 8 weeks in $25{ }^{\circ} \mathrm{C}$ ). However, the HMF did not more than $40 \mathrm{mg} / \mathrm{kg}$ (Codex Standard 12-1981). The increase of the HMF concentration might be to the diminution of the fructose content [15], temperature and time of heating [16-18], storage conditions, use of metallic containers [19] and chemical properties of honey, which are attributed to the floral source from where the honey has been extracted (Figure 7-9). However, no information on the correlation between chemical characteristics and HMF level of honey is available [20].

A. At $25{ }^{\circ} \mathrm{C}$, during the first 4 weeks, DN increased $(5.81 \mathrm{mg} / \mathrm{kg})$. However, DN diminished $(4.46 \mathrm{mg} / \mathrm{kg})$ at 8 weeks but not less than 3mg/kg (Codex Standard 12-1981).

B. At $10{ }^{\circ} \mathrm{C}$, during the first 2 weeks, DN increased $(5.22 \mathrm{mg} / \mathrm{kg})$. However, DN diminished $(4.37 \mathrm{mg} / \mathrm{kg})$ at 8 weeks but not less than $3 \mathrm{mg} / \mathrm{kg}$ (Codex Standard 12-1981).

C. Similar trend was noticed by White et al., (1964). Sancho et al., (1992) reported depletion in diastase number after studied the effect of storage for two years at $20{ }^{\circ} \mathrm{C}$. Cervantes et al. [17] also reported decrease in diastase number after heating the honey at $55{ }^{\circ} \mathrm{C}$ and then storing it for three and half months at $26^{\circ} \mathrm{C}$. Castro-Vazquez et al. [18] also reported that diastase number was out of the legal limit in citrus honey stored for 12 months at $40{ }^{\circ} \mathrm{C}$.

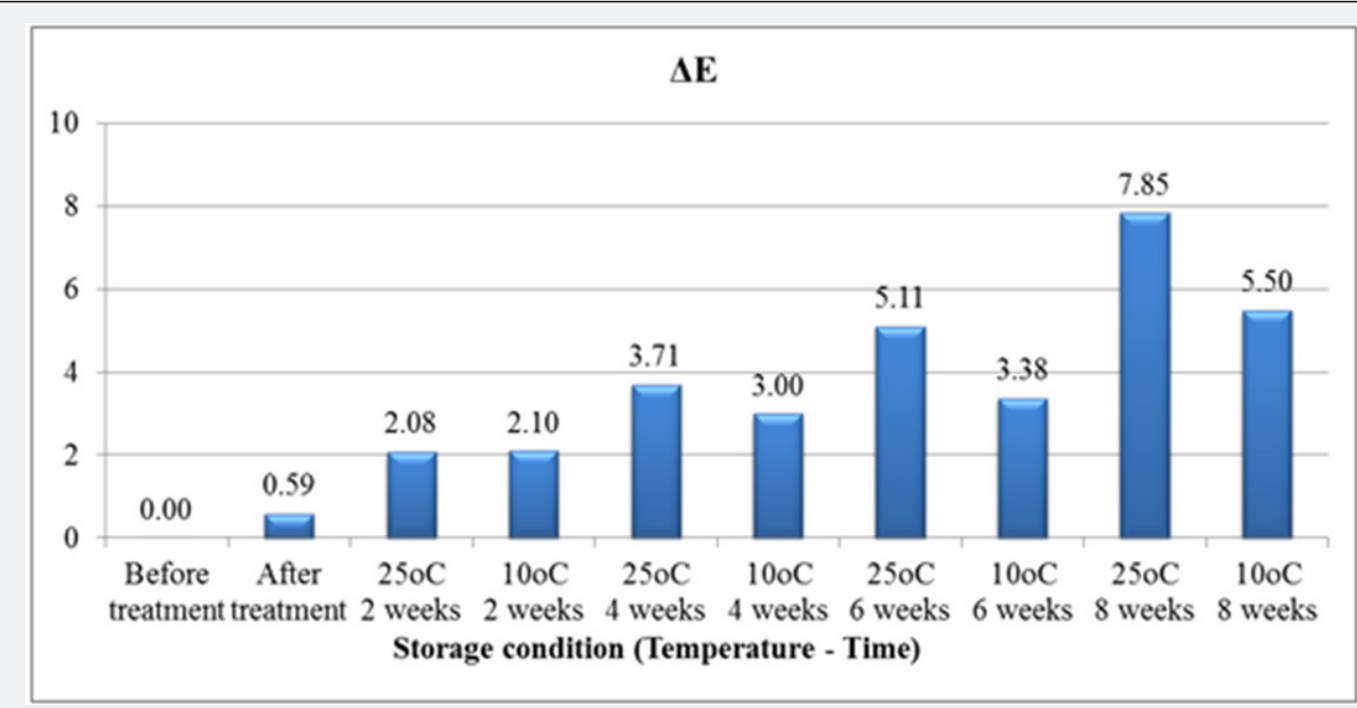

Figure 10: Effect of storage condition after microwave processing on colour.

At temperature $10{ }^{\circ} \mathrm{C}$ and $25{ }^{\circ} \mathrm{C}$, during 8 weeks, there was no significant $(\mathrm{P}<0.05)$ difference in water content. During 8 weeks storage, as shown in Figure 10 for the color function $\Delta \mathrm{E}$ after an initial induction period, it followed a period of increase of color with time $\left(2.08,3.71,5.11,7.85\right.$ at $25{ }^{\circ} \mathrm{C}$ and 2.10 ,
$3.00,3.38,5.50$ at $10{ }^{\circ} \mathrm{C}$ ). This behavior was observed in many products subjected to non-enzymatic browning. During shipping to far countries and/or dring storage, darkening of honey may occur, and paralellel changes in its organoleptic properties have detrimental effects on its quality, masking its original aroma, 
which promotes loss of competitiveness in the world market [20] (Figure 10).

\section{Conclusion}

The results showed that the physico-chemical characteristics of cajuput honey was as follows: water content $23.18 \%$, RS $717.42 \mathrm{mg} / \mathrm{g}$, HMF $4.24 \mathrm{mg} / \mathrm{kg}$, DN $4.85 \mathrm{mg} / \mathrm{kg}$, colour parameters L*a*b* 39.51-10.51-31.81.

Microwave processing applied to cajuput honey did not effect on colour, while RS, HMF, DN and water content affected significantly but still satisfied the limits of Codex Standard 121981. The storage time and temperature affected significantly on RS, DN and colour ( $\Delta \mathrm{E}>3$, large difference).

\section{Acknowledgment}

This research is funded by Vietnam National University HoChiMinh City (VNU-HCM) under grant number C2018-20-21.

\section{References}

1. Bogdanov S, Martin P (2002) Honey Authenticity: a Review, Swiss Bee Reaserch Centre pp. 1-20.

2. Tosi E, Ciappini M, Ré E, Lucero H (2002) Honey thermal treatment effects on hydroxymethylfurfural content. Food Chemistry 77: 71-74.

3. Tosi E, Re E, Lucero H, Bulacio L (2004) Effect of honey hightemperature short-time heating on parameters related to quality, crystallization phenomena and fungal inhibition, LWT - Food Science and Technology 37(6): 669-678.

4. Kowalski S, Lukasiewicz M, Bednarz S, Panus M (2012) Diastase number changes during thermal and microwave processing of honey. Czech Journal of Food Sciences 30(1): 21-26.

5. Günes B, Bayindirli A (1993) Peroxidase and lipoxygenase inactivation during blanching of green beans green peas and carrots, LebensmittelWissenschaft und-Technologie 26(5): 406-410.

6. Matsui KN, Granado LM, De Oliveira PV, Tadini CC (2007) Peroxidase and polyphenol oxidase thermal inactivation by microwaves in green coconut water simulated solutions. LWT-Food Science and Technology 40(5): 852-859.

7. Miller (1959) Use of Dinitrosalicylic Acid Reagent for Detection of Reducing Sugars. Analytical Chemistry 31(3): 426-428.

8. Fallico B, Zappala M, Arena E, Verzea A (2003) Effect of conditioning on HMF content in Unifloral honeys. Food Chem 85: 305-313.

9. Serrano S, Villarejo M, Espejo R, Jordal M (2004) Chemical and physical parameters of Andalusian honey. Food Chem 87: 619-625.

10. Codex Standard for honey.

11. Perez C, Conchello P, Arino A, Juan T, Herresa A (1994) Quality evaluation of Spanish rosemary honey. Food Chem 51: 207-210.

12. Sancho MT, Muniategui S, Huidobro JF, Lozano S (1992) Aging of honey. J Agric Food chem 4: 134-138.

13. Wootten M, Edwards RA, Faraji-Haremi R, Johnson AT (1976) Effect of accelerated storage conditions on the chemical composition and properties of Australian honeys. 1. Colour, acidity and total nitrogen content, Journal of Apicultural Research 15: 23-28.

14. White JW (1992) Honey. Advances in Food Research 24: 287-371.

15. Karabournioti S, Zervalaki P (2001) The effect of heating on honey HMF and invertase. Apiacta 36(4): 177-181.

16. White JW, Kushnir I, Subers MH (2013) Effect of storage and processing temperatures on honey quality. Food Technology 18(4): 153-156.

17. Cervantes MAR (2000) Effect of the temporary thermic treatment of honey on variation of the quality of the same during storage. Apiacta 35: 162-170.

18. Castro-Vázquez L, Díaz-Maroto MC, González-Viñas MA, de la Fuente E, Pérez-Coello MS (2008) Influence of storage conditions on chemical composition and sensory properties of citrus honey. J Agric Food Chem 6: 1999-2006.

19. Labuza TP, Saltmarch M (1980) The non-enzymatic browning reactions as affected by water in foods. In L.B. Rockland, and G.F. Steward, Properties of water related to food quality and stability, pp. 605-650.

20. Milum VG (1939) Honey discoloration and loss of delicate flavor in processing. American Bee Journal 17: 390-392.

\begin{tabular}{l} 
Your next submission with Juniper Publishers \\
will reach you the below assets \\
- Quality Editorial service \\
- Swift Peer Review \\
- Reprints availability \\
- E-prints Service \\
- Manuscript Podcast for convenient understanding \\
- Global attainment for your research \\
- Manuscript accessibility in different formats \\
( Pdf, E-pub, Full Text, Audio) \\
- Unceasing customer service \\
Track the below URL for one-step submission \\
https://juniperpublishers.com/online-submission.php \\
\hline
\end{tabular}

